\title{
Internal displacement and external migration in a post-conflict economy: Perceptions of institutions among migrant entrepreneurs
}

\author{
Nick Williams, et al. [full author details at the end of the article]
}

Published online: 2 May 2019

(C) The Author(s) 2019

\begin{abstract}
This article examines the trust of institutions among internal and external migrant entrepreneurs in the post-conflict economy of Bosnia and Herzegovina. Drawing on survey data and in-depth interviews, we find that external migrant entrepreneurs with international experience have lower trust in institutions than internal migrants. This is explained by the comparison of institutions in the country of origin with more stable institutional environments they experienced while being abroad. Consistent with this
\end{abstract}

\footnotetext{
Summary highlights Contributions: We contribute to institutional theory by examining trust in institutions among external migrants and the internally displaced. The paper finds differences in trust which can be explained by exposure to international environments and the experiences gained among the external migrants. External migrants are exposed to international markets and more stable institutional environments abroad, which changes their perceptions of home. The paper also shows how personal networks have a differential impact on trust, with individuals in more ethnically diverse networks reporting lower trust, demonstrating that institutions are not ethnically neutral.

Research question: How do perceptions of institutions compare between internal and external migrants in conflict affected economies?

Methodology: Our study focuses on the post-conflict economy of Bosnia and Herzegovina. We use a mixed method approach involving survey data of individuals and in-depth interviews with external migrants and the internally displaced. This allows to combine aggregated data with qualitative in-depth analysis so that both sets of data can be cross-validated and corroborated.

Database: This study relies on two databases, including representative survey data from EU Horizon 2020 INFORM project gathered in 2017 (www.formal-informal.eu/home.html) and on the Regional Research Promotion Programe project representative survey data from 2015 (https://seedsdata.unil.ch/project/studypublic-overview/153/0/).

Results/findings: The results show that international external migrants have lower trust in institutions in comparison to internal migrants. This can be explained by their exposure to other institutional environments and thus adds to research regarding international experience and how it is utilised. Many of the external migrants have been based in Western economies with much more stable institutions, which provide a cognitive contrast with the institutions in the homeland. Our findings also demonstrate how personal networks have a differential impact on perceptions, with individuals embedded in more ethnically diverse networks having lower trust in institutions, which we posit is a result of a fragmented political and institutional system as institutions are often not ethnically neutral throughout the country.

Theoretical implications and recommendations for further research: Our study adds to institutional theory by demonstrating differences in institutional trust based on experience of different economic environments. Previous research has examined trust among indigenous entrepreneurs as well as returnees. However, our research takes theory forward through the focus on external and internal migration. Future research could seek to examine external migration and internal displacement associated with different forms of crisis, including economic downturns, political repression and climate change.
} 
conclusion, a more complex institutional setup within the country is associated with lower trust in institutions. We also show that personal network diversity has a differential impact on trust, with individuals in more ethnically diverse areas and networks reporting lower trust, reflecting the possibility that institutions are not ethnically neutral and inclusive enough.

\section{Abstrakt}

Cet article examine la confiance qu'ont les entrepreneurs, issus de migrations internes et externes à la Bosnie-Herzégovine, dans les institutions après la guerre. En travaillant à partir de données d'enquêtes et d'entretiens approfondis, nous avons constaté que les entrepreneurs ayant migré à l'extérieur du pays et donc possédant une expérience internationale, avaient moins confiance dans les institutions que les personnes déplacées à l'intérieur du pays. Ceci s'explique, en partie, par l'expérience comparative que les migrants ont connus entre les institutions de leur pays d'origine et l'environnement institutionnel plus stable qu'ils ont connu à l'étranger. Conformément à cette conclusion, une configuration institutionnelle plus complexe dans le pays est associée à une confiance moindre dans les institutions. Nous montrons également que la diversité des réseaux personnels a un impact différentiel sur la confiance. Les individus appartenant à des zones et à des réseaux plus diversifiés sur le plan ethnique font état d'une confiance moindre, reflétant ainsi la possibilité que les institutions ne soient pas suffisamment neutres et inclusives sur le plan ethnique.

Keywords Migration · Entrepreneurship $\cdot$ Institutions $\cdot$ Perceptions $\cdot$ Networks

Mots-clés Migration · Entrepreneuriat · Institutions $\cdot$ Perceptions $\cdot$ Reseaux

JEL classifications $\mathrm{P} 3 \cdot \mathrm{L} 26 \cdot \mathrm{F} 22 \cdot \mathrm{C} 26$

\section{Introduction}

Displacement of populations is becoming an increasing phenomenon globally. People can be forced to move externally and internally for a number of reasons, including economic crisis, climate change, conflict and persecution (UNHCR 2018). Therefore, understanding these movements is increasingly important and can have implications for a wide range of economies and geographies. Conflict economies experience significant migration, and ongoing economic and demographic challenges post the cessation of violence (Brinkerhoff 2011; Williams and Krasniqi 2018). This leads to the emergence of a displaced population, often outside the country (external migrants) and also within the country's borders (internal migrants). Given the high levels of migration associated with post-conflict countries, governments often seek to mobilise external migrants and their resources to contribute to higher levels of entrepreneurship in their country of origin (Vaaler 2013), as well as fostering entrepreneurial activity internally. Often, such policies are made imperative by weak, underdeveloped institutional environments and low levels of entrepreneurial activity in post-conflict environments (Williams and Vorley 2017). Furthermore, attracting entrepreneurial activity home can be critical in post-conflict economies as it can play a role in 
stabilisation, reconstruction and peace-building (Branzei and Abdelnour 2010), with many countries adopting policies to incentivise investments from those who have moved abroad (Williams 2018).

Entrepreneurial activity can be fostered by the migrants returning to their country of origin in three key ways: first, by direct involvement in the creation of new firms or the management of existing firms; second, by investing in the entrepreneurial activities of others; and, third, by acting as a role model and inspiration to entrepreneurs in the country of origin and for foreign investors (Nielsen and Riddle 2010). However, returns to different forms of entrepreneurial activity are sensitive to institutional contexts (Estrin et al. 2016); this not only impacts entrepreneurial activity in the country of origin but also influences the willingness of entrepreneurs outside the country to invest (Riddle et al. 2010). The institutional framework climate in post-conflict economies may prove daunting for even experienced and well-connected migrant entrepreneurs since the environment is dynamic, changing and marred by institutional deficiencies (Nielsen and Riddle 2010). Institutional environments in post-conflict economies are typically characterised by weak formal institutions and informal institutions (Williams and Vorley 2017). Thus, the general public and entrepreneurs in post-conflict societies, including the Western Balkans region, rely heavily on different informal practices that are used to overcome formal institutional deficiencies and everyday socio-economic challenges (Gordy and Efendic 2019). This can also lead to negative perceptions among migrant communities who view the financial risk to investments, lack of support, political fragmentation and weak institutional framework as barriers to investment (Agunias and Newland 2012).

In this article, we focus on two distinct migrant groups, which have not been studied together previously and which thus allows us to develop key contributions regarding differential perceptions of institutions. As external and internally displaced migrans have not previously been studied together, this allows to contribute to theory regarding the differential motivations and activities of both groups: first, 'traditional' migrants which can be defined as having moved across international borders away from their homeland but who often maintain a relationship with their country of origin or have returned to their country of origin (Riddle and Brinkerhoff 2011). Second, we examine internally displaced persons which have not crossed international borders but have moved within their home country and, mainly, to avoid conflict situations and have been cut off from their home city, town or village. The displaced population often includes some of the most marginalised social groups in society, facing economic and social isolation and poverty (Turner 2010). A key distinction between the two groups is that the external migrants have international experience, gaining from exposure to more developed and stable Western economies, building strong skills, experience and networks (Filatotchev et al. 2009) as well as Eastern economies (Lundberg and Rehnfors 2018), while internally displaced migrants have much more limited opportunities. Moreover, external migrant entrepreneurs sometimes transfer parts of their businesses from abroad (host country) back to the post-conflict environments (home country), which has been identified as very supportive 'translocal' activity to the local economic development (Halilovich and Efendic 2019). With external and internal migration set to increase in future, due to diverse factors such as arm conflicts, climate change, weather shocks and drought, the dynamics, impacts and perceptions of these groups require close attention (World Bank 2016). 
Much of the research on international business focuses on large-scale multinational and transnational corporations (for example, see Meyer et al. 2009). At the individual level, the majority of the literature on migrant communities and entrepreneurship focuses on the international movements to host countries (i.e. the country they have emigrated to), rather than their country of origin (i.e. the country they have emigrated from); see for example, Ram et al. (2008), Vershinina et al. (2011), Wang and Liu (2015) and Lassman and Busch (2015). There is some existing research which examines impacts in both home and host countries (see, for example, Patel and Conklin 2009; Lundberg and Rehnfors 2018) and a small literature on the home country (see, for example, Gillespie et al. 1999; Nielsen and Riddle 2010; Riddle et al. 2010; Gamlen et al. 2017). Still, there is a lack of literature on internally displaced migration and entrepreneurship, and no work, to our knowledge, which compares internal and external migrants simultaneously. As such, our study contributes to theory regarding internal migration and internal displacement, filling a gap in the current literature. Given that migration is a growing phenomenon and people are moving across international borders more than ever before (United Nations 2017), while at the same time, approximately 70 million have been forcibly displaced (UNHCR 2018), understanding such movements are increasingly important.

In order to fill this gap, our central research question is: 'How do perceptions of institutions compare between internal and external migrants in conflict affected economies?', with a particular reference to entrepreneurs. Institutional trust is a prerequisite for productive entrepreneurial activity (Anokhin and Schulze 2009), yet there is no existing research on different perceptions of internal and external migrants and the impact this has on entrepreneurship. As such, the paper contributes to research by showing the different perceptions of trust when comparing internal and external migrants and including both entrepreneurs and ordinary citizens. In comparing internal and external migrants, we show that external migrants are exposed to international markets and more stable institutional environments abroad, which changes their perceptions of home. We also contribute to the literature by showing how personal networks have a differential impact on trust, with individuals in more ethnically diverse networks reporting lower trust, demonstrating that institutions are not ethnically neutral or inclusive in such postethnic conflict environments.

The article's empirical focus is on Bosnia and Herzegovina (hereafter $\mathrm{BiH}$ ), which has experienced significant migration to other parts of the world, particularly as a result of the war of the 1990s and the break-up of the former Yugoslavia. This emigration has left the country not only with a sizable migrant community spread around the world (Babic 2013), equal to over $50 \%$ of the current population today (MHRRBiH 2016), but also with the challenge of developing a relatively weak economy. $\mathrm{BiH}$ also experienced significant internal migration, with around one million (around 25\% of the population) displaced from their homes (IOM/IASCI 2010). BiH is seeking to harness the potential of its migrant communities in order to enhance economic development, with part of the responses including attempts to directly engage and mobilise investment, as well as institutional reform aimed at improving the overall business environment (MHRR 2016). While the empirical elements of our study are drawn from $\mathrm{BiH}$, we provide theoretical and practical implications for other similar countries with complex 
institutional environments, including post-conflict and transition economies (e.g. the rest of the Western Balkans region).

The remainder of the article is structured as follows. First, the literature on the role of migrant communities - external and internal-in their home institutional environment is discussed, outlining the importance of institutional trust. We then set out the empirical focus of $\mathrm{BiH}$, along with the methodology used, before the findings of the data are analysed. The article concludes by reflecting on the analysis and identifies contributions to scholarship on internal and external return migrant entrepreneurship.

\section{Literature review}

\section{External and internal migration of entrepreneurs}

External migrants can be defined by the dispersion of ethnic and national groups across international borders (Smallbone et al. 2010) and who often maintain a relationship to their home country (Safran 1991; Riddle and Brinkerhoff 2011). External migrants who then return home can act as drivers of change (Lin et al. 2018), and this return is often driven by an emotional connection (Williams 2018). Migrant communities often adopt transnational characteristics which are a mix of learned cultural and social behaviours from their home country and host country and are also able to develop trans-local communities (Halilovich 2012). These characteristics can then be harnessed to benefit their home country, through the sharing of capital, technical knowledge, expectations of how business should be conducted, direct investment, impacts on wages and the harnessing of entrepreneurial activity (Smallbone et al. 2010; World Bank 2016; Hausmann and Nedelkoska 2018). However, harnessing the entrepreneurial intentions of returning migrants can be challenging in environments where institutions are dynamic and changing and where perceptions of risk and lack of trust act as barriers to activity (Nielsen and Riddle 2010; Krasniqi and Williams 2018).

In a formal sense, external migrants can connect businesses and business networks across borders (Elo 2016). In addition, informal connections are also important with first-generation migrants likely to have stronger connections with family and friends at home (Mayer et al. 2015). Such network connections, whether formal or informal, can reduce 'space' between countries and facilitate international trade (Williams 2018) and can also mean that external migrants who return are able to overcome the 'liability of foreignness' associated with outside investment (Zaheer 1995). As trust builds slowly especially with nondomestic entities who might have little reputation within the target market, the process of international expansion can be slow and gradual (Autio 2017). However, through informal networks of family and friends, pride and an enhanced sense of self can support activity. Indeed, external migrants who return can overcome the liability by becoming (re)connected with local constituents and developing understanding of social, cultural and institutional changes at home (Li et al. 2012).

Returning migrants can contribute to their home country through the transfer of knowledge, where skills and ideas are shared across international borders 
(Riddle et al. 2010). By working and undertaking education in their host countries, migrant communities accumulate human capital that can be invested for productive purposes in their home countries (Riddle and Brinkerhoff 2011). Migrants often increase their educational level and/or gain new skills, save money and extend their social network while living abroad (Naude et al. 2015). In doing so, active migrant communities can serve as a vital bridge between their host countries and home countries, promoting and facilitating economic and political ties (Levin and Barnard 2013). While migrant networks vary in terms of the number of actors they incorporate, their location, the benefits they provide to individual members and the strength of relations between network actors, all of which can influence economic activity (Smallbone et al. 2010), these transnational characteristics allow members of migrant communities to operate intermediary roles between countries as they possess an advantage of deeper understanding of social and business environments internationally (Riddle et al. 2008). Networks offer migrant entrepreneurs invaluable and unique competitive advantages, making them fundamental to the growth and success of their own businesses, and a potential resource for harnessing entrepreneurship in their home country. Migrants who operate abroad often gain knowledge and skills that are lacking in the home country (Nielsen and Riddle 2010). When they return to invest or start a new business, they remit this acquired human capital back to the home country, thereby turning 'brain drain' into 'brain gain' (Filatotchev et al. 2009).

Despite the potential impacts of the returning migrants, mobilising them is challenging for policy makers (Brinkerhoff 2017; Williams 2018). Migrant entrepreneurs need to have a positive perception of their home country if they are to invest and/or move back to launch new ventures (Nielsen and Riddle 2010). Migrant entrepreneurs can be less risk averse, as evidenced by their decision to migrate, itself a risky activity and at the same time may be better able to spot opportunities for new businesses as they have already spotted opportunities for migration (Naude et al. 2015). However, immigrants can be found more proportionately among the self-employed because they may be excluded from more formal wage opportunities, hence they may be driven into selfemployment (Naude et al. 2015). We posit, though, that in the case of forced migration (for example, in situations of conflict), risk aversion will be a key factor in preventing entrepreneurial activity, with a lack of institutional trust born out of international experience. Given that individuals can move away from a country at war, with little choice or sense of 'opportunities' available to them elsewhere, and then be faced with returning to a country with significant economic and social challenges, it is likely that risk aversion will be prevalent. Mobilising their return is hampered by fragmented political systems and weak institutional environments, which combine to contribute to (negative) poor levels of trust.

While the dynamics of external migration are growing fields in entrepreneurship research (Brinkerhoff 2016), much less is known regarding internally displaced populations or internal migrants. Clearly, there are key differences between an external and internal migrant, with internal migrants lacking the international experience and resources of external migrants. However, they also cannot be considered as traditional entrepreneurs in the sense that have the same perceptions and opportunities as the indigenous (non-displaced) population. Indeed, given their experiences of migration, 
often forced due to conflict, they are likely to have different levels of institutional trust as well as reduced opportunities.

Some existing studies have explored the role of entrepreneurship in the context of conflict, demonstrating that entrepreneurship can create positive economic and social impacts on those affected (Bullough et al. 2014). Yet the majority of these studies do not focus on displacement, which creates a unique context for those affected and significant barriers to opportunity (Cheung and Kwong 2017). Within internally displaced populations, entrepreneurship may provide a viable option, enabling them to overcome structural employment challenges (Harima and Freiling 2016). Yet local knowledge and resources will be harder to acquire for external migrants due to their relative lack of familiarity with the host location (Cheung and Kwong 2017). In addition, previous networks can become obsolete due to the rapid departure and dispersion of the population (Harima and Freiling 2016). Bullough et al. (2014) highlight the role of self-efficacy in the creation of entrepreneurial intention in conflict situations; those who are displaced may be less likely to believe that they can succeed as entrepreneurs due to these knowledge, resource and network limitations. As such, the internally displaced may require different strategies towards entrepreneurship in order to overcome these barriers.

\section{Institutions and trust in post-conflict environments}

Migrant communities can maintain an altruistic tie to their homeland which makes them an ideal target for policy makers (Nielsen and Riddle 2010), and in order to ensure that they are mobilised, it is important that the institutional environment is supportive and stable so that trust can be engendered (Vorley and Williams 2016). Institutions refer to the formal and informal constraints designed by people to structure interactions, and these constraints can shape incentives for market actors, such as by shaping predicted rewards and risks (North 1990; Williams et al. 2017a, b). In post-conflict and transition economies, institutions are identified to be an important factor affecting economic development (e.g. Efendic and Pugh 2015), while at the same time, these environments are often characterised by weak formal institutions and informal institutions which are unsupportive of entrepreneurial activity (Williams and Vorley 2017). In such situations, there is 'little incentive for entrepreneurs to commit themselves to long term projects forcing them instead to concentrate on the task of surviving' (Smallbone and Welter 2001, p. 260). Where formal institutions, which consist of rules and regulations governing economic activity, create trust, individuals will view opportunities more positively (Busenitz et al. 2000). Such regulations assign property rights, and where these are poorly defined or not enforced, the risk of expropriation of entrepreneurial returns is increased (Estrin et al. 2016). Where such expropriation exists, productive entrepreneurs can see assets liquidated, their venture terminated and proceeds consumed by others (Desai et al. 2013). Indeed, where entrepreneurs are subject to uncertainty, in the form of changing regulations, the bureaucracy and the cost of compliance can impose increased operational and transaction costs and increase the risks associated with entrepreneurial activity (Tonoyan et al. 2010). It is not only the enforcement of the formal institutions but also their reliability or volatility that is important (Krasniqi and Desai 2016). In environments with frequent changes in 
formal laws, rules and regulations, uncertainty is created, meaning that entrepreneurs are less able to plan for the future and a lack of trust is created (Williams and Vorley 2015). This is especially salient in economies where institutional change can be faster and less predictable (Ahlstrom and Bruton 2010), including post-conflict economies were formal institutions are being established (Nielsen and Riddle 2010).

Navigating institutional frameworks is always challenging for entrepreneurs (Estrada-Robles et al. 2018). Yet this is particularly so for migrants who may never have lived in the home country, have lived abroad for a number of years or who know relatively few people in the country (Nielsen and Riddle 2010). While migrant entrepreneurs are often the first mover foreign investors into uncertain political and economic climates (Gillespie et al. 2001), such activity may be stymied where there is a lack of trust. Where the social fabric has been damaged, the level of trust is low and people may be unwilling to share knowledge, which can stymie entrepreneurial endeavours (Efendic et al. 2015). Institutional trust is a critical element in fostering productive entrepreneurial activity (Anokhin and Schulze 2009), and we posit that where trust is lacking, international migrants can simply chose to remain abroad, while internal migrants avoid what they perceive as risky activities. In countries undergoing significant change, such as transition or post-conflict scenarios, trust in institutions is not likely to be immediate and will take time to develop (Krasniqi and Desai 2016). However, given the importance of networks to international as well as internal migrants, even where trust is lacking, network access utilisation can counteract the negative perception associated with trust. Where formal institutions are seen to be weak, migrant entrepreneurs can utilise formal and informal networks, either internally or traversing international borders (Levin and Barnard 2013; Halilovich and Efendic 2019). In this sense, formal institutions are substituted for through collaboration with the local network (Doh et al. 2017).

Our literature review establishes that the distinction of entrepreneurs based on their migration experience - being external, internal or non-migrant — can be an important factor in explaining variations of the trust and confidence in institutions of post-conflict environments. The difference might occur since the external migrant entrepreneurs have gained international experience and skills coming from exposure to more developed and stable institutional environments and Western European markets. Contrary, internal migrant entrepreneurs have much more limited experience and general opportunities to develop their skills and comparative perceptions. Such structural difference between their status and entrepreneurial performance affects their perceptions of the same institutional contexts, leading to a more critical approach of external migrant entrepreneurs.

\section{Empirical focus}

The wars of the 1990s led to the breakup of the former Yugoslavia and creation of a number of newly independent states (former Yugoslav republics). While waves of emigration began earlier, starting in 1960s in response to limited employment opportunities (Zbinden et al. 2016), the wars accelerated the movement of people abroad and within the country. BiH suffered heavily during the war of the 1992-1995, and the legacy of war is still one of a rather segregated country along the ethnic lines (Efendic and Pugh 2018). It is now home to very complicated systems of government, which 
began with the Dayton Peace Accords of 1995 that successfully ended the conflict. At the first level, there is national government, followed with entity governments with predominantly Bosniak-Croat entity, the Federation of $\mathrm{BiH}(\mathrm{FBiH})$ and the other entity which is Serb dominated, the Republika Srpska; at the second level, there are 10 cantons but only in FBiH entity; and at the third level, there are over 140 municipalities. Dayton achieved its immediate purpose of putting an end to the bloodshed but had mainly institutionalised ethnic divisions inherited from the war period. As Halilovich (2012) states, displacement caused by the war revived traditional local and ethnic identities within the country, as well as producing new categories of individuals, including 'stayers' and 'leavers', 'newcomers' and 'old settlers', 'defenders' and 'deserters', internally displaced persons (IDPs) and refugees. BiH changed from a country of ethnic diversity to ethnic homogeneity in some areas (Efendic et al. 2011) and where the three main ethnic groups (Bosniaks, Serbs and Croats) have substantial autonomy and control over their own ethno-territorial units (Bieber 2010). Yet, in spite of all these changes, there are regions within the country in which ethnic diversity is still preserved, which provides fertile grounds for grater business aspirations and better individual economic performance (Efendic et al. 2015; Efendic and Pugh 2018).

$\mathrm{BiH}$ has failed to effectively reform formal institutions, with Efendic et al. (2011) finding that minority ethnic groups are less confident in formal institutions and substitute them with more reliance on informal institutions, and other research which shows that entrepreneurs can substitute formal institutions through collaboration with local actors (Doh et al. 2017). BiH's external migrant population is estimated at approximately two million, equivalent to over $50 \%$ of the current population (MHRR 2016). In the aftermath of the wars, remittances from these migrants became increasingly important (King and Vullnetari 2009), with the value estimated at over $10 \%$ of the country's GDP (MHRR 2016). Policies related to migrants are being driven by the acute economic, social and demographic challenges in the country, which require greater levels of entrepreneurship and innovation to create jobs for current and future generations, as well as European Union accession requirements, despite $\mathrm{BiH}$ not being an official candidate (Domm 2011).

\section{Methods}

In order to examine perceptions of institutions among external and internal migrants, we utilise a mixed methods approach, combining a representative survey of individuals and in-depth interviews with entrepreneurs in $\mathrm{BiH}$. Such an approach complements existing research which uses mixed methods to study entrepreneurial phenomena (Crilly 2011). Mixed methods are appropriate as both quantitative and qualitative methods have weaknesses which are, to an extent, compensated for by the strengths of the other (Creswell 2003). Furthermore, mixed methods have been used for the study of entrepreneurship so that aggregated data can be combined with in-depth studies of individual perceptions and experiences and to enable data to be cross-validated and corroborated (Jack and Anderson 2002; Kisfalvi 2002). While the quantitative element aims to identify whether there is a structural difference in institutional trust between internal and external migrants, in-depth interviews are used to reveal the main causes of such differences. Thus, these are complementary methods giving us possibility to say more about the phenomena in focus. 


\section{Survey}

The survey was undertaken over the period June-August 2015. ${ }^{1}$ The survey was implemented by a professional research agency on a sample of 6021 randomly selected respondents. ${ }^{2}$ The sample is representative of 138 out of 141 municipalities in $\mathrm{BiH}$ and was conducted via computer-assisted telephone interviewing (CATI). It was prepared in a special survey program The Survey System 9.0. The survey was designed so that each municipality should have at least 40 participants and at least 6000 respondents in total. Standard questions from entrepreneurship surveys ('Are you, alone or with others: a. currently the owner of a business that you help manage, b. trying to start a business ...') are asked to check if respondents have either established or nascent businesses. In the sample, we obtain that $5.3 \%$ of respondents are entrepreneurs, giving us an effective sample of 321 entrepreneurs. There are around $10 \%$ of entrepreneurs who are former migrants or, more precisely, 38 entrepreneurs belong to this category, of which 28 have established and 10 nascent businesses. We treat the both categories as entrepreneurs, since the sample is rather small and we cannot make further disaggregation. Moreover, we use a more recent data (collected in 2017) on institutional trust in $\mathrm{BiH}$ from an EU horizon project $\left(\mathrm{H} 2020, I N F O R M^{3}\right)$, which gives us possibility to check if there have been structural changes in trust over recent years.

\section{In-depth interviews}

The in-depth interview stage built on the findings of the survey to explore key issues in more detail. This ensured that the survey approach informed the development of the indepth interview stage, with both approaches complementing each other. In utilising indepth interviews, key themes were identified through the survey and a semi-structured approach allowed the research to follow emerging lines of interest and to be partially guided by the participants. This study therefore focused on exploring the constructions of meaning that occur in the interview setting, and what is important is not how the researchers define impacts of this migrant entrepreneurship but how the participants define it. Interviews are inherently intersubjective, and no objective, impersonal record

\footnotetext{
$\overline{1}$ This database is produced within the project "Social capital and migration-evidence from a post-conflict environment", which is funded by the Regional Research Promotion Programme (RRPP). The RRPP is coordinated and operated by the Interfaculty Institute for Central and Eastern Europe (IICEE) at the University of Fribourg (Switzerland). The programme is fully funded by the Swiss Agency for Development and Cooperation (SDC), Federal Department of Foreign Affairs.

${ }^{2}$ The technique of random selection by closest birthday was used to implement the survey. Upon the first contact, the interviewers asked about the number of persons living in one apartment or house and who are between 16 and 65 years old. The interviewers conducted the interview with selected household member whose birthday was closest to the date they are interviewing. If that person was not at home, they arranged callback, if possible. The software schedules the callbacks five times before dropping out the number. This method ensures random selection of respondents. In the final dataset, there are 44 observations per municipality; on average, the minimal number per municipality is 40 while the maximum is 46 .

${ }^{3}$ INFORM is a project that brings together teams from nine European countries to conduct multidisciplinary social science research on formal and informal institutions in the Balkans. The 3-year research project, launched in March 2016, is carried out in the framework of the Horizon 2020 programme. INFORM project has received funding from the European Union's Horizon 2020 research and innovation programme under grant agreement no. 693537.
} 
of their lived experience is accessible or liable to representation in an academic article (Essers and Benschop 2007).

Interviews were undertaken with 30 migrant entrepreneurs (external and internal) and the qualitative approach allows the researcher to capture context richness and diversity by examining actions, intentions and perceptions (Hlady-Rispal and JouisonLaffitte 2014). ${ }^{4}$ Qualitative research in challenging environments has the potential to improve understanding of entrepreneurs' experiences and provide rich data which quantitative survey-based approaches cannot provide (Doern 2009), especially in post-conflict and nascent institutional environments (Williams and Vorley 2017). In the initial stage, the important criteria was to identify migrants in the both entities of $\mathrm{BiH}$, as they are having different institutional setups explained earlier, which might also affect perceptions of migrants differently. Moreover, the search for external migrants was designed to capture different sectors of the economy. Potential participants were initially contacted via telephone and then a snowball sampling technique was applied. Snowball sampling is a method particularly useful for undertaking research on sensitive topics and accessing 'hidden' populations and more suitable for small sample sizes (Hendricks and Blanken 1992). Indeed, there is no database on migrant entrepreneurs in $\mathrm{BiH}$, they are rare (around $12 \%$ of the total entrepreneurs in our sample) and difficult to find. In such circumstance, the snowballing method was a useful strategy of the missing data collection. The limitation of this approach might be a bias caused by nonprobabilistic sampling, but this is mainly the case if the sample is used for quantitative estimation techniques, which is not the problem of this study (Beauchemin and Gonzalez-Ferrer 2011). Appendix 1, Table 2 provides a profile of the participants in terms of the sectors of their business operations, the entity in which they operate, the year that they emigrated from $\mathrm{BiH}$ or migrated within $\mathrm{BiH}$, the year they permanently returned and finally whether they were external or internal migrants.

Many of the migrant entrepreneurs (85\%) left BiH because of the war (1992-1995), and the average time spent abroad in our sample is 6 years. Eighty percent of them were successful in finding employment abroad and gaining different skills that they use in today businesses. Although they are entrepreneurs, still over $60 \%$ of them claim that different emotional links and nostalgia are the main reasons for return to $\mathrm{BiH}$, not economic reasons, while some state that they were pushed to move back by the host countries. Also, the strong emotional links to the home places are indicative by the fact that around $90 \%$ of entrepreneurs returned to municipalities they lived in prior to migration. Internal migrants have moved within the country due to different reasons, including primarily displacement due to war, but in some cases other influences such as the economic factors. While majority of returning migrant entrepreneurs returned to their home municipalities, the internal migrants in our sample have moved mainly to different locations rather than to their home cities.

The interviews lasted in the range 45-90 min and were recorded with the respondent's consent. They were then transcribed, before assuming a grounded approach

\footnotetext{
${ }^{4}$ The interviews with external migrant entrepreneurs were collected as part of a research project carried out by the Economic Institute Sarajevo in cooperation with the University of Neuchatel's Swiss Forum for Migration and Population Studies (SFM) on behalf of the Swiss Agency for Developmetn and Cooperation (SDC) and the Federal Office for Migration (FOM). More information about these data is available in Efendic et al. (2014). The authors have additionally conducted five interviews with internal migrants in 2017 to enable comparisons.
} 
towards thematically analysing and coding the data to explore emergent themes. It was important, in keeping with Bryman (2012), that the reliability of coding was consistent and structured in order to prevent coder bias. Therefore, the coding process was conducted independently by the authors, with overarching thematic categories identified to develop a coding scheme based on key themes so that intra-coder reliability could be consistent. This coding scheme was applied by both authors, and the results of it were then compared to ensure inter-coder reliability by identifying any discrepancies between the coders so that they could be revisited and agreed. This constant comparative method involves continually identifying emergent themes against the interview data and employing analytic induction whereby the researcher identifies the nature of a relationship and develops the narrative (Silverman 2000). The qualitative approach was particularly appropriate to enable entrepreneurs to articulate how they perceive their impacts in their home country, and quotes from the interviews are used to provide enhancement and to add voice to the study. In many cases, consensus was found regarding the key areas of exploration and these responses can therefore be considered to be representative of the views of the majority of the respondents. The key questions asked of the respondents are set out in Appendix 2, Table 3, along with a summary of responses which represent the most representative quotes from the interviewees.

\section{Findings}

In this study, we examine institutional trust, i.e. confidence in institutions at different administrative levels in $\mathrm{BiH}$ presented earlier. The in-depth interviews found that 'Generally speaking, trust in BiH institutions is very low (INT 4, INT28)', with a few examples that report a positive feedback (e.g. INT6, INT30). As the main reasons for the lack of confidence, the entrepreneurs identify lack of institutional efficiency, which is linked primarily to time wasting and burdensome administrative procedures (e.g. INT4, INT5, INT8, INT16, INT18, INT24, INT27, INT28, INT29). As an outcome, entrepreneurs report that sometimes ' ... you must wait for a year to get one document (INT8)'. The respondents stated that 'Bosnia has been very slow to reform' and remained an unstable environment (INT25) in which employees of these institutions are protected, they face no competition nor threat for their positions, and in such circumstances do not have incentives to improve their efficiency (INT4). This is common to institutional environments in post-conflict countries (Williams et al. 2017a, b).

Yet we also show differences in perceptions of internal and external migrants. Interestingly, our in-depth interviews found that external entrepreneurs compared the institutional environments in contrasting ways. For some, the institutional complexity of $\mathrm{BiH}$ is something they have not experienced ' ... after several years of working in different countries' (INT16, INT9, INT24). For others, this was a challenge because they found that the 'life (abroad) was too predictable' (INT25) in their host country and that the comparative institutional instability in their home country created challenges which were interesting to try to overcome. Rather than putting them off launching an entrepreneurial venture, the institutional environment of $\mathrm{BiH}$ provided the impetus to 'seek out a challenge' with emotional ties pulling them back home. In discussing the institutional environment, the external migrants were often philosophical about the challenges, with one stating that 'nowhere is it $100 \%$ guaranteed that your business will succeed ... there are problems everywhere that you have to overcome' (INT25) and " 


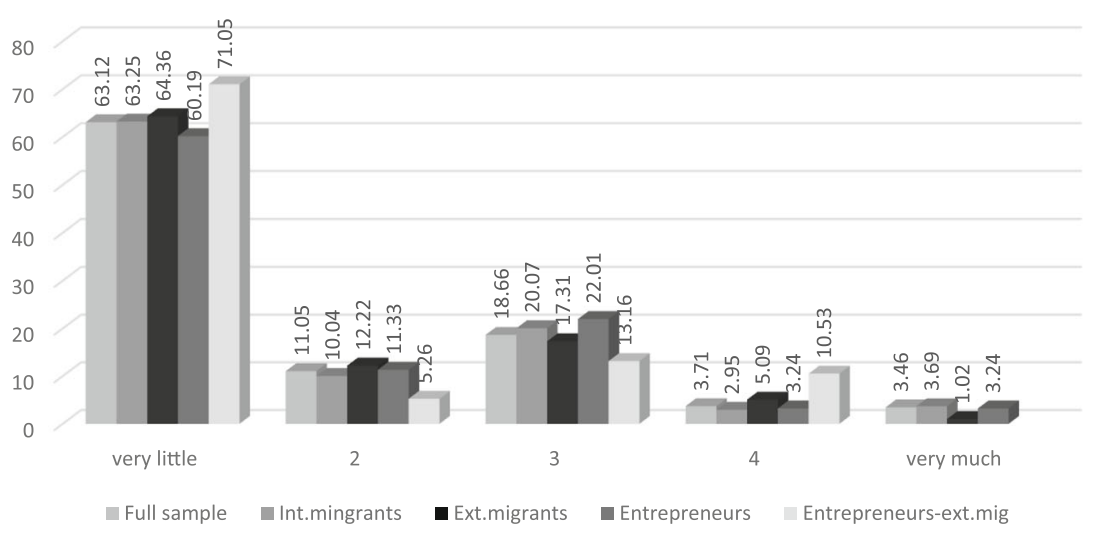

Fig. 1 Confidence in $\mathrm{BiH}$ institutions: an aggregated index for different migrant categories

... none should expect positive results immediately; it takes time like for everything and everywhere' (INT22).

The survey asked 'Could you tell us how much confidence you have in state/entity/ municipality institutions?' with a scale ranging from 1-'very little' to 5-'very much'. The majority of respondents report that they have very little confidence in these different institutional levels, with very little response chosen by $60 \%, 59 \%$ and $57 \%$ for state, entity and municipal institutions respectively. Since the scale is identical for all types of institutions, we investigate if it would be feasible to establish an aggregated index of institutional trust. The factor analysis obtained the Eigenvalue for the first factor 2.8 and drops to -0.02 for the second factor. All factor loadings are above 0.95 . Since this checking has supported aggregation, we establish an aggregated index of institutional trust by combining these responses and dividing them by three. Visual interpretation of the aggregated index of institutional trust is presented in Fig. 1, where we distinguish responses for different migrant categories (internal and external), including those who are entrepreneurs. Figure 1 shows that external migrants have lower trust in institutions in comparison to ordinary (non-migrant) citizens and internal migrants, while external migrants who are entrepreneurs have the lowest confidence in the sample and in comparison to entrepreneurs in general.

We compare these results with a more recent data (2017) from BiH coming from a representative survey conducted as a part of INFORM project introduced earlier. ${ }^{5}$ The survey has the same question that is used in this study, but it has a different scale and cannot be compared directly. However, the obtained results are similar and again reveal a low level of trust in institutions, including both for ordinary citizens and for entrepreneurs identified in the sample.

We also investigated the mean differences ${ }^{6}$ of trust in institutions and other relevant variables that we use in our empirical modelling — age, gender, education, employment

\footnotetext{
${ }^{5}$ More about the project and survey data can be found at: http://www.formal-informal.eu/home.html.

${ }^{6}$ We rely on two-sample $t$ test with unequal variances to assess the difference between the samples. The tests are implemented in statistical software STATA14 using command ttesti.
} 
and entrepreneurial status of respondents - for internal and external migrant subsamples. Compared to internal migrants, external migrants have lower confidence in institutions ( -0.08 on a 5-point scale; $p=0.073$ ), are more entrepreneurial (there is $2 \%$ more entrepreneurs among external migrants; $p=0.059)$ and are also more educated $(7 \%$ more respondents with secondary and high education; $p=0.001)$. However, we do not identify a significant difference between internal and external migrant samples for employment status, risk aversion and age variables. These results indicate that external migrants not only are more critical of institutional environment of their home country once they return, but they also systematically report or bring higher educational skills and more entrepreneurial activity into this society (identified as relevant experience gained abroad by 23 out of 25 external migrant entrepreneurs). We conclude that external migrants pose a higher level of human capital and stronger entrepreneurial spirit then internal migrants and as such provide an 'imported' development potential in this post-conflict society. However, it seems that institutional support is lagging behind and there is a need to do much more in the institutional setup that will complement the external entrepreneurs' aspirations and expectations. The in-depth interviews also found that trust issues were an important consideration for entrepreneurs. Often this meant that engagement with the government was avoided. For example, one respondent stated that: 'Politicians can't be trusted. We need a new generation of politicians who are not there because of their connections ... if government wanted to support my business I would avoid it because I know that they would want a stake in it or a bribe at some point' (INT1).

Through the survey, we further estimate empirical models trying to identify what causes these variations in trust for different migrant groups. To estimate these relationships, we use trust in institutions (insttrustd) as the dependent variable. In the final modelling procedure, we rely on a binary dependent variable for institutional trust, since the obtained model diagnostics with the original scale (or logged transformation) estimated with OLS suggested a problem with functional form (Ramsey RESET test was not satisfactory). The best statistical diagnostics we obtain is if we use the dependent variables as binary variables, where 0 means 'very little trust' and 1 there is some trust. This motivated a binary Probit model to be our base choice for estimation. To investigate determinants of institutional trust, we rely on three types of factors that might be relevant for this post-conflict economy.

Firstly, we control for typical individual characteristics including potential effects of age (Age), gender (Male), area of living (Urban, Suburban or Rural), educational level (Educat) and employment status (Femploy). These are all binary variables which we use to make interpretation with marginal effects easier. Although employment status might not be an individual characteristic typically used in similar research, we argue that in our model, it might have an important role. The official unemployment is very high and reported to be over $40 \%$ (although ILO estimate is much lower and being over $20 \%$ ) and is a key macroeconomic problem in the country, which is also perceived as an institutional failure (Efendic et al. 2011). Employment experience can affect individual trust in institutions and help us to identify if this had a systematic effect on individual trust.

The next groups of determinants that we control for are post-conflict specific influences linked to potential effects of ethnic diversity. There is evidence that 
institutional environment had formalised ethno-established positions during the Bosnian war (Bieber 2010), causing number of ethnically related challenges and leaving the institutional power under effective control of dominant majority throughout the country. Accordingly, individuals from the same ethnicity if living in more ethnically homogenous or ethnically diverse areas (Mixed) might have different trust in these ethnically governed institutions. In the same vein, at individual level, we might have variations in perceptions caused by the more ethnically homogenous or heterogeneous personal contact networks (Diversity) established by these individuals. Following some previous research (e.g. Efendic et al. 2011), we expect more trust in institutions in ethnically homogenous areas dominated by a majority ethnic group and, consequently, by individuals having ethnically homogenous contact networks.

As we introduced earlier, the $\mathrm{BiH}$ institutional framework is uniquely specific while institutional structure in one entity (Federation of $\mathrm{BiH}$ ) is much more complex than in the other one (Republika Srpska), leading to overlapping jurisdictions and higher direct and indirect costs (Efendic et al. 2011). It is thus important to control for the effect of different institutional structures (Fbih, Rsbih, Dbbih) or institutional asymmetry between entities as they might differently influence the trust in institutions. Through these variables, we control for the effect of differences in formal institutional environments. Finally, we control if respondents are entrepreneurs or not (Entrepreneur), as the main variable of interest. Linked to this status and our discussion of existing literature, we also control for the risk aversion of the interviewed individuals (Risk), expecting that those who are not willing to take more risk are having less confidence in post-conflict established institutions.

Descriptive statistics of variables used in modelling procedure are presented in Appendix 3, Table 4. The results of Probit model, which is estimated with clusterrobust standard errors (to correct the effect of heteroscedasticity identified in the data), are reported in Table 1. As clusters, we use municipalities. This table contains marginal coefficients obtained after Probit estimates as they provide useful interpretation. We report the results for the full $\mathrm{BiH}$ sample (model 1), sub-samples including model 2 for migrant population (internal and external migrants together) and then for internal migrants who were moving only within $\mathrm{BiH}$ (model 3) and, finally, for external migrants (model 4), i.e. those being abroad and who moved back to BiH. Finally, as part of our robustness procedure, we report in Appendix 4, Table 5 the OLS estimate.

Beginning with individual characteristics, we find a very stable and positive influence of employment status in all estimated models (models 1-4). Simply, those who are employed report systematically more trust in institutions in comparison to those who are not employed or who are outside of the labour force. Such a result implies that a better economic status of individuals in this post-conflict environment influences their trust in institutions. In addition to this finding, the effect of age is significant and negative in all models (models 1-3) but not for the ex-migrants (model 4). A negative coefficient implies that older respondents report lower trust in institutions in comparison to the younger once.

In terms of the effect of institutional environment, we do find a negative, high and significant effect of $\mathrm{FBiH}$ entity in all models. Respondents from the $\mathrm{FBiH}$ report around $10 \%$ systematically lower trust in comparison to respondents from the 
Table 1 Determinants of institutional trust: Probit cluster-robust estimate, marginal effects reported

The dependent variable is Insttrustd: very little trust $=0$; there is some trust $=1$

\begin{tabular}{|c|c|c|c|c|}
\hline \multirow[t]{2}{*}{ Variable } & Model 1 & Model 2 & Model 3 & Model 4 \\
\hline & $\begin{array}{l}\text { Full sample } \\
\text { for } \mathrm{BiH}\end{array}$ & $\begin{array}{l}\text { Migrant } \\
\text { subsample }\end{array}$ & $\begin{array}{l}\text { Internal } \\
\text { migrants }\end{array}$ & $\begin{array}{l}\text { External } \\
\text { migrants }\end{array}$ \\
\hline \multicolumn{5}{|l|}{ Individual characteristics } \\
\hline Age & $-0.003 * * *$ & $-0.003 * *$ & $-0.004 * * *$ & -0.001 \\
\hline Male & -0.024 & -0.004 & -0.010 & 0.022 \\
\hline Educat & 0.005 & -0.033 & -0.036 & -0.015 \\
\hline Femploy & $0.052 * * *$ & $0.118 * * *$ & $0.118 * * *$ & $0.114 *$ \\
\hline Urban & -0.018 & 0.034 & 0.039 & 0.034 \\
\hline Suburban & -0.032 & -0.046 & $-0.071 *$ & 0.024 \\
\hline \multicolumn{5}{|l|}{ Institutional environment } \\
\hline Fbih & $-0.108 * * *$ & $-0.100 * * *$ & $-0.082 * *$ & $-0.130 * * *$ \\
\hline Dbbih & 0.030 & $-0.073 * * *$ & $-0.055^{*}$ & -0.037 \\
\hline \multicolumn{5}{|l|}{ Post-conflict ethnic influences } \\
\hline Diversity & -0.002 & -0.050 & -0.001 & $-0.195 * * *$ \\
\hline Mixed & -0.027 & -0.040 & -0.013 & $-0.010^{*}$ \\
\hline \multicolumn{5}{|l|}{ Entrepreneurial factors } \\
\hline Risk & $0.155^{* * *}$ & $0.146^{* * * *}$ & $0.141 * * *$ & $0.182 * * *$ \\
\hline Entrepreneur & -0.027 & -0.047 & 0.002 & $-0.181 * *$ \\
\hline \multicolumn{5}{|l|}{ Model diagnostics } \\
\hline No. of observations & 3834 & 1297 & 937 & 360 \\
\hline Wald test ( $p$ value) & 0.000 & 0.000 & 0.000 & 0.000 \\
\hline Hosmer-Lemeshow test ( $p$ value) & 0.10 & 0.25 & 0.58 & 0.65 \\
\hline Predicted probability & 0.38 & 0.38 & 0.38 & 0.37 \\
\hline
\end{tabular}

The variable of particular interest 'entrepreneur' obtained the $p$ value of 0.018

$* * *, * *$ and $*$ denote statistical significance of the estimated coefficient at the $1 \%, 5 \%$ and $10 \%$ respectively

Republika Srpska. This outcome is not surprising given that institutional structure in $\mathrm{FBiH}$ is more complex; it shows more problems in its coordination and functioning, which can be reflected in the trust of these institutions. It comes out that a more complex institutional setup decreases confidence in institutions, which also identifies a need for structural institutional reforms in this entity.

The coefficients estimated for post-conflict ethnic influences in the models all appear with negative sign, but being significant in the external migrant sample only. This finding suggests that respondents living in more diverse areas and having more diverse ethnic networks are systematically (20\%) less confident in institutions than those having more homogenous networks. Ethno-established institutions which are governed by majorities are likely to get more trust in ethnically homogenous areas and by individuals having such personal homogenous networks rather than in ethnically diverse environments and from individuals establishing such personal contacts. 
Finally, we control two factors relevant for entrepreneurial effects in the model. We do find a consistent and high effect of personal risk aversion in all estimated models. Respondents being ready to take more risk, which is a general feature of entrepreneurs, report $15 \%$ better trust in institutions, on average. In addition to this, while the effect of entrepreneurial status is not significant in other models, once it is estimated for ex-migrant entrepreneurs (model 4), this variable has a significant negative effect, and a rather high magnitude of $18 \%$. Simply, exmigrant entrepreneurs report systematically lower trust in institutions in comparison to non-entrepreneurs.

Further results can be obtained by looking at the combined effects of different determinants in the model. We focus our attention on interactions between entrepreneurial status and ethnic diversity influence, as this has been specifically linked to external migrants (model 4). We estimate interactions by augmenting model 4 with the two-way interactions between the variables of interest (Entrepr, Mixed, Diversityd). All these estimates are adjusted for multiple comparisons by the Bonferroni method (STATA 2011, p. 1554). Although entrepreneurial status does have a high individual effect (0.18), when combined with personal network diversity (Diversityd) it decreases trust in institutions quite significantly (combined marginal coefficient is $-0.32, p$ value $=0.001$ ). For example, entrepreneurs having ethnically diverse network have $32 \%$ less trust in institutions than nonentrepreneurs having ethnically homogeneous networks. Simply, these effects build if they are combined. The combined effects with diversity of areas (Mixed) are not statistically significant.

As part of robustness procedures, we estimate OLS models (Appendix 4, Table 5), but the obtained results remain fully consistent with some noteworthy differences in the estimated coefficients. In addition, if we estimate a parsimonious model by excluding insignificant variables (at the 10\% level), again, the obtained results are fully consistent. As the main limitation of our empirical investigation, we see a standard challenge of using cross-sectional data which limits our choice of specification, deeper investigation and addressing potential endogeneity in the model, especially in the context of education and employment influences that are assumed to be exogenous.

\section{Conclusions}

The aim of this article was to examine the perceptions of institutions of internal and external migrants. The majority of literature on migrant entrepreneurship examines impacts in the host country, with less focusing on home country impacts. Furthermore, there is no existing study which unpacks the differences between the perceptions of internal and external migrant. As such, we contribute to the literature by comparing these groups and providing implications for theory and policy. Our mixed methods approach allows to compare the experiences of external and internal migrants in depth, allowing data to be combined with the lived experiences of entrepreneurs (Jack and Anderson 2002).

The paper focuses on $\mathrm{BiH}$ which experienced significant emigration as a result of the war of the 1990s, and associated economic and political challenges, and has left the 
challenge of fostering higher levels of entrepreneurship which can contribute to postconflict recovery (Doh et al. 2017). Emigration has left the country with a sizable migrant community spread around the world. Yet significantly, $\mathrm{BiH}$ also experienced high levels of internal migration, with people displaced from their homes within the country's borders due to the conflict. The in-depth interviews found that external migrants have a strong emotional tie to $\mathrm{BiH}$ which gives them a desire to assist in the future development of the country. This means that despite the inherent institutional challenges they face, and which compare negatively with the stable institutional environments that the external migrants experienced in more developed economies, they do not stop migrants from launching entrepreneurial ventures.

Our results contribute to theory regarding institutional trust. We find that international external migrants have lower trust in institutions in comparison to internal migrants. This can be explained by their exposure to other institutional environments and thus adds to research regarding international experience and how it is utilised. Many of the external migrants have been based in Western economies with much more stable institutions, which provide a cognitive contrast with the institutions in $\mathrm{BiH}$. While these external migrants will have gained valuable skills and experience (Riddle and Brinkerhoff 2011), it has also provided insight into the deficient institutions at home.

Our findings also demonstrate how personal networks have a differential impact on perceptions. Individuals with more ethnically diverse networks report lower trust in institutions. While the reasons for this finding are complex, we posit that it is a result of the fragmented political and institutional system in $\mathrm{BiH}$, as institutions are often not ethnically neutral throughout the country. For example, the political division between the Federation of $\mathrm{BiH}$ and the Republika Srpska maintains a stark reminder of previous tensions as well as perpetuating the partition of institutions. Networks are of crucial importance to migrant entrepreneurs either returning to their homeland or who have been internally displaced. While networks vary in size, location and benefit (Smallbone et al. 2010), they provide access to resources that are unavailable to outsiders. Returnees use professional and personal ties when launching businesses in the home country (Pruthi et al. 2018). While more diverse networks are generally regarded as beneficial for business development and individual and family incomes (Efendic et al. 2015; Efendic and Pugh 2018), if there is an institutional discrimination based on ethnicity, the effect of diversity can diminish. Perceptions of discrimination will affect willingness to return and invest (Poblete 2018). This deserves further investigation not only in post-conflict economies but also other evolving institutional environments.

Acknowledgments We would like to thank to anonymous referees and the editor of this study who helped us to improve the paper by their valuable comments. This study relies on representative survey data supported by the Regional Research Promotion Programme (RRPP) from 2015 (https://seedsdata.unil.ch/project/studypublic-overview/153/0/). In addition, we use survey data from the EU Horizon 2020 INFORM project, 2017 (www.formal-informal.eu/home.html).

Funding information The Regional Research Promotion Programme (RRPP) was fully funded by the Swiss Agency for Development and Cooperation. The EU Horizon 2020 INFORM project, 2017, has received funding from the European Union's Horizon 2020 research and innovation programme under grant agreement No 693537 . 


\section{Appendix 1}

Table 2 Profile of respondents

\begin{tabular}{|c|c|c|c|c|c|c|}
\hline Interviews & Entity & Sector & $\begin{array}{l}\text { Year company } \\
\text { was established }\end{array}$ & $\begin{array}{l}\text { Year of } \\
\text { migration }\end{array}$ & $\begin{array}{l}\text { Year of } \\
\text { return }\end{array}$ & $\begin{array}{l}\text { Internal or } \\
\text { external migrant }\end{array}$ \\
\hline INT1 & $\mathrm{FBIH}$ & Service & 2002 & 1980 & 1999 & External \\
\hline INT2 & FBIH & Service & 1999 & 1992 & 1999 & External \\
\hline INT3 & RS & Agriculture & 2011 & 2003 & 2008 & External \\
\hline INT4 & FBIH & Industry & 1996 & 1986 & 1996 & External \\
\hline INT5 & $\mathrm{FBIH}$ & Trade & 1998 & 1991 & 1995 & External \\
\hline INT6 & RS & Agriculture & 2008 & 1993 & 1998 & External \\
\hline INT7 & $\mathrm{RS}$ & Trade & 2002 & 1992 & 2000 & External \\
\hline INT8 & $\mathrm{RS}$ & Trade & 2012 & 1995 & 1997 & External \\
\hline INT9 & $\mathrm{RS}$ & Service & 2001 & 1991 & 2000 & External \\
\hline INT10 & $\mathrm{RS}$ & Trade & 2012 & 1992 & 1997 & External \\
\hline INT11 & $\mathrm{RS}$ & Service & 2001 & 1992 & 1997 & External \\
\hline INT12 & FBIH & Service & 1996 & 1992 & 1995 & External \\
\hline INT13 & FBIH & Service & 1998 & 1992 & 1996 & External \\
\hline INT14 & $\mathrm{RS}$ & Food ind. & 1994 & 1993 & 2005 & External \\
\hline INT15 & FBIH & Trade & 1997 & 1996 & 2002 & External \\
\hline INT16 & $\mathrm{RS}$ & Service & 2003 & 1995 & 2003 & External \\
\hline INT17 & FBIH & Service & 2010 & 2000 & 2003 & External \\
\hline INT18 & FBIH & Mortgages & 2005 & Born abroad & 2003 & External \\
\hline INT19 & $\mathrm{RS}$ & Food ind. & 2005 & 1995 & 1995 & External \\
\hline INT20 & $\mathrm{RS}$ & Service & 2002 & 1992 & 2002 & External \\
\hline INT21 & $\mathrm{FBIH}$ & Service & 2011 & 1992 & 1996 & External \\
\hline INT22 & RS & Service & 1997 & 1995 & 1998 & External \\
\hline INT23 & $\mathrm{RS}$ & Service & 1986 & 1970 & 1983 & External \\
\hline INT24 & $\mathrm{RS}$ & Food ind. & 2008 & 1979 & 2009 & External \\
\hline INT25 & FBIH & Food ind. & 2000 & 2012 & 2012 & External \\
\hline INT26 & FBIH & Real estate & 2014 & 2010 & - & Internal \\
\hline INT27 & FBIH & Consulting & 2010 & 2006 & - & Internal \\
\hline INT28 & $\mathrm{FBIH}$ & Textile & 1988 & 1973 & - & Internal \\
\hline INT29 & FBIH & Trade & 2016 & 2004 & - & Internal \\
\hline INT30 & $\mathrm{RS}$ & Car repair & 2007 & 1995 & - & Internal \\
\hline
\end{tabular}




\section{Appendix 2}

Table 3 Summary of the most representative quotes from informants

Key questions $\quad$ Summary of key responses

What is your level of confidence in institutions?

- If I need to mark my confidence in institutions using the range 1 (minimum) to 5 (maximum), my answer will be 2 , maximum 2.5 . The main reasons is that $\mathrm{I}$ do not see much change in their efficiency. Contrary, our business sector, private sector, has improved a lot over the last few years, which has not been followed by appropriate institutional improvements. The main reason for such trends is a lack of competition in the state institutions. If they know that they can lose a job they would be much more efficient, but in our current institutional setup everyone who is working for these institutions is fully protected and cannot loose his/her job. Without imposing some competition in the institutional sector nothing will change and they will remain inefficient. (INT4)

- After fifteen years being in business my experience with government institutions is a little bit better now and I have a bit more confidence than it was the case before. Although there are number of other challenges, I can say, thanks to the Good, there is some improvement and I am also more confident now. (INT18)

- The trust in institutions depends primarily on the people who provide the services of those institutions. The trust varies because experiences are different. Depending on what day it is, who is that you talk to, and so on, ..., sometimes you finish what you need quite fast but sometimes it postpones significantly. Currently we have an issue with a client who has started a new business in the field that is new to our region. While trying to obtain licences and register the business we have had a lot of obstacles from the institutions because of the administrative personnel working there did not quite understand the business and they were reluctant to help because of being scared to make a mistake. Also, different employees interpret the Law differently so to complete the same action you often have to go through different procedures. (INT27)

- Generally speaking, the trust is really low. It all depends on what you want to do and who is the responsible person for your action. For example, only few years ago in our municipality you would have to wait days just to get one document. With some improvements, the new governor has shortened this time-wasting procedures significantly. However, still it depends a lot on the administration. (INT28) 
Table 3 (continued)

Key questions $\quad$ Summary of key responses

- To be honest, people working in our institutions have no clue of how things should be done. I opened two shops and really had a tough time. To put it simply, people working in administration do not know what the next step is after you finish with them and often send you to wrong addresses. So, probably more than half of your visits to institutions will be knocking on wrong doors because of this. This deteriorates the trust significantly. (INT29)

- I have trust in institutions. I did not have any particular problem with them. For example, when I was starting my business I engaged a lawyer who finished all procedures for me in some 15-20 days, and alter on I did not have any particular problem. (INT30)

What are the main institutional barriers for your business?
- To change and ease the procedures of establishing companies, to code the applications for establishment in order to avoid submitting them under individual name and surname as primary element, because the current way is subject to manipulations. (INT4)

- It is a problem of institutional infrastructure and therefore it is much easier to do business through connections and acquaintances. (INT5)

- Well, there was no any particular barriers, people are just talking about it ... (INT6)

- It is a problem that you must wait for a year to get one document. The complete business climate is rather negative (INT8)

- I would have closed my shop a long time ago had it not been for my relatives from Germany who usually cover my losses. However, this strategy works no more, and unfortunately, I will have to close my shop and emigrate there as well. (INT9)

- The issues were mostly of administrative nature. My husband and I were really surprised about how much time it takes to register a company, especially after several years working at different countries. And the process of finding appropriate employees was also highly time-consuming. (INT16)

- Administration is the worse, definitely the biggest problem. (INT17)

- Well, the bureaucracy should be reduced and the process of opening companies accelerated, and in my opinion, it would be beneficial for attracting the foreign investors if they had certain subsidies during the first years of their investments. (INT18)

- I would like to compare the situation in $\mathrm{BiH}$ with the one we have in Switzerland. I receive updated information about activities and events from Switzerland on regular basis. Here, we cannot offer people anything to inform them about culture and tradition, not even the $\mathrm{BiH}$ diaspora. (INT24)

- There are problems in legal sector, especially when it comes to collecting receivables. Despite having all 
Table 3 (continued)

Key questions Summary of key responses

documentation and judgement on debt collection, it is impossible to implement it. Also, the inspections provide no education at all, they primarily have the purpose of collecting finances. (INT24)

Would you recommend to other entrepreneurs from

It is only important to have a good business idea diaspora to invest in $\mathrm{BiH}$ ? (external migrants because people in $\mathrm{BiH}$ are willing to work. (INT5) only)

- It is logical that the diaspora should invest in $\mathrm{BiH}$. There is a lot of money here (at least in the context of natural resources and potentials). (INT8)

- Unfortunately, two years ago I was in a position that one businessmen asked me for advice to invest 2-3 million of Euros in $\mathrm{BiH}$, and I could not say about my positive experience. May opinion is linked to all problems that I faced, and one is that mentality here is not oriented towards entrepreneurship. (INT15)

- It worth investing in $\mathrm{BiH}$ but this should be done with trusty people .... I would recommend the diaspora to invest in $\mathrm{BiH}$ and the main reason is to keep our resources from foreigners and from destruction. We have so many rivers; if we only work with rivers ... It is said what we are doing to our forests. (INT19)

- It is the most important that they clued up about the business environment in $\mathrm{BiH}$. And certainly, they will need some support, at least for a few years when they decide to start their business here. You should not expect positive results immediately; it takes time like for everything and everywhere. Probably, joint ventures with domestic partners are the best solution. (INT22)

- I do not recommend investing while the political situation in the country does not change. There is a need to say that it is not only responsibility of politicians, but also of the people living here. (INT24) 


\section{Appendix 3}

Table 4 Descriptive statistics of key variables

\begin{tabular}{|c|c|c|c|c|c|c|c|c|}
\hline \multirow[b]{3}{*}{ Variables } & \multirow[b]{3}{*}{ Description of variables } & \multirow{2}{*}{\multicolumn{3}{|c|}{$\frac{\text { Full sample }}{\text { Bosnia and Herzegovina }}$}} & \multirow{2}{*}{\multicolumn{2}{|c|}{$\begin{array}{l}\text { Internal } \\
\text { migrants only }\end{array}$}} & \multirow{2}{*}{\multicolumn{2}{|c|}{$\begin{array}{l}\text { External } \\
\text { migrants only }\end{array}$}} \\
\hline & & & & & & & & \\
\hline & & $\begin{array}{l}\text { Number } \\
\text { of } \\
\text { observ. }\end{array}$ & Mean & $\begin{array}{l}\text { Do not } \\
\text { knows/ } \\
\text { na }\end{array}$ & $\begin{array}{l}\text { No. of } \\
\text { observ. }\end{array}$ & Mean & $\begin{array}{l}\text { No. of } \\
\text { observ. }\end{array}$ & Mean \\
\hline \multicolumn{9}{|c|}{ The dependent variable } \\
\hline Insttrust & $\begin{array}{l}\text { Institutional trust, factor variable: } \\
\text { very little }=1 \\
\text { to very much }=5\end{array}$ & 5284 & 1.70 & $12.2 \%$ & 1355 & 1.70 & 491 & 1.62 \\
\hline Insttrustd & $\begin{array}{l}\text { Institutional trust as binary: } \\
\text { very little trust }=0 \text {; there } \\
\text { is some trust }=1\end{array}$ & 5284 & 0.37 & $12.2 \%$ & 1355 & 0.37 & 491 & 0.36 \\
\hline \multicolumn{9}{|c|}{ Individual characteristics } \\
\hline Age & $\begin{array}{l}\text { Age of respondents: } 16 \text { to } \\
65 \text { years }\end{array}$ & 6021 & 47.10 & $0.0 \%$ & 1555 & 48.97 & 536 & 48.55 \\
\hline Male & Gender: $0=$ female; $1=$ male & 6021 & 0.45 & $0.0 \%$ & 1555 & 0.34 & 536 & 0.45 \\
\hline Educat & $\begin{array}{l}\text { Education: } 0=\text { no and primary; } \\
1=\text { secondary and high }\end{array}$ & 5993 & 0.71 & $0.5 \%$ & 1551 & 0.73 & 534 & 0.80 \\
\hline Femploy & $\begin{array}{l}\text { Employment status: } 0=\text { not } \\
\text { employed; } 1=\text { employed }\end{array}$ & 6004 & 0.27 & $0.3 \%$ & 1549 & 0.29 & 536 & 0.30 \\
\hline Urban & Urban area: $0=$ no; $1=$ yes & 6021 & 0.28 & $0.0 \%$ & 1555 & 0.32 & 536 & 0.36 \\
\hline Suburban & Suburban area: $0=$ no; $1=$ yes & 6021 & 0.24 & $0.0 \%$ & 1555 & 0.31 & 536 & 0.29 \\
\hline Rural & $\begin{array}{l}\text { Rural area: } 0=\text { no; } 1=\text { yes } \\
\quad \text { (base category) }\end{array}$ & 6021 & 0.48 & $0.0 \%$ & 1555 & 0.37 & 536 & 0.35 \\
\hline \multicolumn{9}{|c|}{ Institutional environment } \\
\hline Fbih & $\begin{array}{c}\text { Entity in } \mathrm{BiH}: 0=\text { other; } \\
1=\text { Federation } \mathrm{BiH}\end{array}$ & 6021 & 0.57 & $0.0 \%$ & 1555 & 0.50 & 536 & 0.54 \\
\hline Rsbih & $\begin{array}{l}\text { Entity in BiH: } 0=\text { other; } \\
\quad 1=\text { Republika Srpska (base) }\end{array}$ & 6021 & 0.42 & $0.0 \%$ & 1555 & 0.50 & 536 & 0.45 \\
\hline Dbbih & $\begin{array}{c}\text { Entity in BiH: } 0=\text { other; } \\
1=\text { District of Brcko }\end{array}$ & 6021 & 0.01 & $0.0 \%$ & 1555 & 0.01 & 536 & 0.01 \\
\hline \multicolumn{9}{|c|}{ Ethnic influences } \\
\hline Diversity & $\begin{array}{l}\text { Personal network is ethnically: } \\
0=\text { non-mixed; } 1=\text { mixed }\end{array}$ & 4566 & 0.55 & $24.2 \%$ & 1145 & 0.56 & 408 & 0.65 \\
\hline Mixed & $\begin{array}{l}\text { The area is ethnically: } \\
0=\text { non-mixed; } 1=\text { mixed }\end{array}$ & 5831 & 0.31 & $3.2 \%$ & 1508 & 0.34 & 518 & 0.36 \\
\hline \multicolumn{9}{|c|}{ Entrepreneurial factors } \\
\hline $\begin{array}{l}\text { Entre- } \\
\text { preneur }\end{array}$ & $\begin{array}{l}\text { Entrepreneurial status: } \\
\begin{array}{l}0=\text { non-entrepreneur; } \\
1=\text { entrepreneur }\end{array}\end{array}$ & 6021 & 0.05 & $0.0 \%$ & 1555 & 0.05 & 536 & 0.07 \\
\hline Risk & $\begin{array}{l}\text { Willing to take a risk: } 0=\text { no at } \\
\text { all; } 1=\text { ready to take some risk }\end{array}$ & 5563 & 0.70 & $7.61 \%$ & 1424 & 0.71 & 505 & 0.74 \\
\hline
\end{tabular}




\section{Appendix 4}

Table 5 Determinants of institutional trust: OLS cluster-robust estimate

The dependent variable is Insttrustd: very little trust $=0$; there is some trust $=1$

\begin{tabular}{|c|c|c|c|c|}
\hline Variable & $\begin{array}{l}\text { Model } 1 \\
\text { Full sample } \\
\text { for BiH }\end{array}$ & $\begin{array}{l}\text { Model } 2 \\
\text { Migrant } \\
\text { subsample }\end{array}$ & $\begin{array}{l}\text { Model } 3 \\
\text { Internal } \\
\text { migrants }\end{array}$ & $\begin{array}{l}\text { Model } 4 \\
\text { External } \\
\text { migrants }\end{array}$ \\
\hline \multicolumn{5}{|l|}{ Individual characteristics } \\
\hline Age & $-0.002 * * *$ & $-0.002 * *$ & $-0.003 * *$ & -0.001 \\
\hline Male & -0.023 & -0.002 & -0.008 & 0.023 \\
\hline Educat & 0.004 & -0.034 & -0.037 & -0.019 \\
\hline Femploy & $0.050 * * *$ & $0.113 * * *$ & $0.113 * * *$ & $0.100 *$ \\
\hline Urban & -0.016 & 0.035 & 0.040 & 0.048 \\
\hline Suburban & -0.029 & -0.043 & $-0.065^{*}$ & 0.021 \\
\hline \multicolumn{5}{|l|}{ Institutional environment } \\
\hline Fbih & $-0.104 * * *$ & $-0.096^{* * *}$ & $-0.077 * *$ & $-0.157 * * *$ \\
\hline Dbbih & 0.028 & $-0.074 * * *$ & $-0.054 *$ & -0.079 \\
\hline \multicolumn{5}{|l|}{ Post-conflict ethnic influences } \\
\hline Diversity & -0.001 & -0.002 & -0.003 & $-0.184 * * *$ \\
\hline Mixed & -0.024 & -0.039 & -0.012 & $-0.101 *$ \\
\hline \multicolumn{5}{|l|}{ Entrepreneurial factors } \\
\hline Risk & $0.151 * * *$ & $0.141 *$ & $0.133 * * *$ & $0.178 * * *$ \\
\hline Entrepreneur & -0.026 & -0.046 & -0.005 & $-0.178^{* *}$ \\
\hline \multicolumn{5}{|l|}{ Model diagnostics } \\
\hline No. of observations & 3834 & 1297 & 937 & 360 \\
\hline F test ( $p$ value) & 0.000 & 0.000 & 0.000 & 0.000 \\
\hline R-squared & 0.04 & 0.05 & 0.05 & 0.10 \\
\hline Ramsey RESET test ( $p$ value) & 0.99 & 0.51 & 0.96 & 0.67 \\
\hline Variance inflation factor test (mean) & 1.11 & 1.15 & 1.15 & 1.18 \\
\hline
\end{tabular}

The variable of particular interest 'entrepreneur' obtained the $p$ value of 0.029 . The constant is estimated but not reported in the table

$* * *, * *$ and $*$ denote statistical significance of the estimated coefficient at the $1 \%, 5 \%$ and $10 \%$ respectively

Open Access This article is distributed under the terms of the Creative Commons Attribution 4.0 International License (http://creativecommons.org/licenses/by/4.0/), which permits unrestricted use, distribution, and reproduction in any medium, provided you give appropriate credit to the original author(s) and the source, provide a link to the Creative Commons license, and indicate if changes were made.

\section{References}

Agunias DR, Newland K (2012) Developing a roadmap for engaging diasporas for development: a handbook for policy makers and practitioners in home and host countries. International Organization for Migration, Geneva 
Ahlstrom D, Bruton GD (2010) International management: strategy and culture in the emerging world. Mason, South-Western

Anokhin S, Schulze WS (2009) Entrepreneurship, innovation and corruption. J Bus Ventur 24:465-476

Autio E (2017) Strategic entrepreneurial internationalization: a normative framework. Strateg Entrep J 11(3):211-227

Babic B (2013) The migration-development nexus in Bosnia and Herzegovina: Center for Local Development and Diaspora seen 'from below'. South Eur Black Sea Stud 13(2):211-225

Beauchemin C, Gonzalez-Ferrer A (2011) Sampling international migrants with origin-based snowballing method: new evidence on biases and limitations. Demogr Res 25:103-134

Bieber F (2010) Post-war bosnia: ethnicity, inequality and public sector governance. Palgrave MacMillan, London

Branzei O, Abdelnour S (2010) Another day, another dollar: enterprise resilience under terrorism in developing countries. J Int Bus Stud 41(5):804-825

Brinkerhoff J (2011) Diasporas and conflict societies: conflict entrepreneurs, competing interests or contributors to stability and development. Confl Secur Dev 11(2):115-143

Brinkerhoff J (2016) Institutional reform and diaspora entrepreneurs: the in-between advantage. Oxford University Press, Oxford

Brinkerhoff J (2017) Diaspora policy in weakly governed arenas and the benefits of multipolar engagement: lessons from the Coptic Orthodox Church in Egypt. J Ethn Migr Stud 45:561-576. https://oi. org/10.1080/1369183X.2017.1409168

Bryman A (2012) Social research methods, 4th edn. Oxford University Press, Oxford

Bullough A, Renko M, Myatt T (2014) Danger zone entrepreneurs: the importance of resilience and selfefficacy for entrepreneurial intentions. Entrep Theory Pract 38(3):473-499

Busenitz LW, Gomez C, Spencer JW (2000) Country institutional profiles: unlocking entrepreneurial phenomena. Acad Manag J 43(5):994-1003

Cheung CWM, Kwong C (2017) Path-and place-dependence of entrepreneurial ventures at times of war and conflict. Int Small Bus J:026624261769180. https://doi.org/10.1177/026624617691802

Creswell JW (2003) Research design: qualitative, quantitative and mixed method approaches. Sage, London

Crilly D (2011) Predicting stakeholder orientation in the multinational enterprise: a mid-range theory. J Int Bus Stud 42(5):694-717

Desai S, Acs Z, Weitzel U (2013) A model of destructive entrepreneurship: insight on conflict and postconflict recovery. J Confl Resolut 57(1):20-40

Doern R (2009) Investigating barriers to SME growth and development in transition environments: a critique and suggestions for developing the methodology. Int Small Bus J 27(3):275-305

Doh J, Rodrigues S, Saka-Helmhout A, Makhija M (2017) International business responses to institutional voids. J Int Bus Stud 48(3):293-307

Domm R (2011) Next steps on Bosnia-Herzegovina: key elements to a revised EU strategy. South Eur Black Sea Stud 11(1):53-67

Efendic A, Pugh G (2015) Institutional effects on economic performance in post-socialist transition: a dynamic panel analysis. Acta Oecon 65(4):503-523

Efendic A, Pugh G (2018) The effect of ethnic diversity on income - an empirical investigation using survey data from a post-conflict environment. Economics 12(2018-17):1-34. https://doi.org/10.5018/economicsejournal.ja.2018-17

Efendic A, Pugh G, Adnett N (2011) Confidence in formal institutions and reliance on informal institutions in Bosnia and Herzegovina - an empirical investigation using survey data. Econ Transit 19(3):521-540

Efendic A, Babic B, Rebmann A (2014) Diaspora and development in Bosnia and Herzegovina. Embassy of Switzerland in Bosnia and Herzegovina, Sarajevo

Efendic A, Mickiewicz T, Rebmann A (2015) Growth aspiration and social capital: young firms in a postconflict environment. Int Small Bus J 33(5):537-561

Elo M (2016) Typology of diaspora entrepreneurship: case studies in Uzbekistan. J Int Entrep 14(1):121-155

Essers C, Benschop Y (2007) Enterprising identities: female entrepreneurs of Moroccan or Turkish origin in the Netherlands. Organ Stud 28(1):49-69

Estrada-Robles M, Williams N, Vorley T (2018) Navigating institutional challenges: the role of social capital in entrepreneurial families. Int J Entrep Behav Res. https://doi.org/10.1108/IJEBR-05-2017-0180

Estrin S, Mickiewicz T, Stephan U (2016) Human capital in social and commercial entrepreneurship. J Bus Ventur 31(4):449-467

Filatotchev I, Liu X, Buck T, Wright M (2009) The export orientation and export performances of hightechnology SMEs in emerging markets: the effects of knowledge transfer by returnee entrepreneurs. J Int Bus Stud 40(6):1005-1021 
Gamlen A, Cumming ME, Vaaler PM (2017) Explaining the rise of diaspora institutions. J Ethn Migr Stud 45: 492-516. https://doi.org/10.1080/1369183X.2017.1409163

Gillespie K, Riddle L, Sayre E, Sturges D (1999) Diaspora interest in homeland investment. J Int Bus Stud 30(3):623-634

Gillespie K, Sayre E, Riddle L (2001) Palestinian interest in homeland investment. Middle East J 55(2):237-255

Gordy E, Efendic A (2019) Meaningful reforms in the Western Balkans - between formal institutions and informal practices. Peter Lang, Bern

Halilovich H (2012) Trans-local communities in the age of transnationalism: Bosnians in diaspora. Int Migr 50(1):162-178

Halilovich H, Efendic N (2019) From refugees to trans-local entrepreneurs: crossing the borders between formal institutions and informal practices in Bosnia and Herzegovina. https://doi.org/10.1093/jrs/fey066

Harima A, Freiling, J. (2016) Workshop on refugee entrepreneurship. ICSB2016, 15.-18. June, 2016, New York/New Jersey, USA

Hausmann R, Nedelkoska L (2018) Welcome home in a crisis: effects of return migration on the non-migrants' wages and employment. Eur Econ Rev 101:101-132

Hendricks VM, Blanken P (1992) 'Snowball sampling: theoretical and practical considerations'. In: VM Hendricks et al. (ed) Snowball sampling: a pilot study on cocaine use. Rotterdam: IVO

Hlady-Rispal M, Jouison-Laffitte (2014) Qualitative research methods and epistemoloigcal frameworks: a review of publication trends in entrepreneurship. Journal of Small Business Management 52(4):594-614

International Agency for Source Country Information/International Organization for Migration (IASCI/IOM) (2010) Maximizing the development impact of migration-related financial flaws and investment to Bosnia and Herzegovina. IOM, Geneva

Jack SL, Anderson AR (2002) The effects of embeddedness on the entrepreneurial process. J Bus Ventur 17(5):467-487

King R, Vullnetari J (2009) Remittances, return, diaspora: framing the debate in the context of Albania and Kosovo. South Eur Black Sea Stud 9(4):385-406

Kisfalvi V (2002) The entrepreneur's character, life issues, and strategy making: a field study. J Bus Ventur 17(5):489-518

Krasniqi BA, Desai S (2016) Institutional drivers of high-growth firms: country-level evidence from 26 transition economies. Small Bus Econ 47(4):1075-1094

Krasniqi BA, Williams N (2018) Migration and intention to return: entrepreneurial intentions of the diaspora in post-conflict economies. Post-Commun Econ:1-20. https://doi.org/10.1080/14631377.2018.1505696

Lassman A, Busch C (2015) Revisiting native and immigrant entrepreneurial activity. Small Bus Econ 45(4):841-873

Levin DZ, Barnard H (2013) Connections to distant knowledge: interpersonal ties between more and less developed countries. J Int Bus Stud 44(7):676-698

Li H, Zhang Y, Li Y, Zhou LA, Zhang W (2012) Returnees versus locals: who perform better in China's technology entrepreneurship? Strateg Entrep J 6(3):257-272

Lin D, Zheng W, Lu J, Liu X, Wright M (2018) Forgotten or not? Home country embeddedness and returnee entrepreneurship. J World Bus 54(1):1-13

Lundberg H, Rehnfors A (2018) Transnational entrepreneurship: opportunity identification and venture creation. J Int Entrep 16(2):150-175

Mayer SD, Harima A, Freiling J (2015) Network benefits for Ghanaian Diaspora and returnee entrepreneurs. Entrep Bus Econ Rev 3(3):95-122

Meyer KE, Estrin S, Bhaumik SK, Peng MW (2009) Institutions, resources, and entry strategies in emerging economies. Strateg Manag J 30(1):61-80

Ministry for Human Rights and Refugees of Bosnia and Herzegovina (MHRRBiH) (2016) Diaspora and development of Bosnia and Herzegovina. MHRRBiH, Sarajevo

Naude W, Siegel M, Marchand K (2015) Migration, entrepreneurship and development: a critical review. IZA DP No. 9284. IZA, Bonn

Nielsen TM, Riddle L (2010) Investing in peace: the motivational dynamics of diaspora investment in postconflict economies. J Bus Ethics 89(4):435-448

North DC (1990) Institutions, institutional change and economic performance. Cambridge University Press, New York

Patel PC, Conklin B (2009) The balancing act: the role of transnational habitus and social networks in balancing transnational entrepreneurial activities. Entrep Theory Pract 33(5):1045-1078

Poblete C (2018) Shaping the castle according to the rocks in the path? Perceived discrimination, social differences, and subjective wellbeing as determinants of firm type among immigrant entrepreneurs. J Int Entrep 16(2):276-300 
Pruthi S, Basu A, Wright M (2018) Ethnic ties, motivations, and home country entry strategy of transnational entrepreneurs. J Int Entrep 16(2):210-243

Ram M, Theodorakopoulos N, Jones T (2008) Forms of capital, mixed embeddedness and Somali enterprise. Work Employ Soc 22(3):427-446

Riddle L, Brinkerhoff JM (2011) Diaspora entrepreneurs as institutional change agents: the case of Thamel.com. Int Bus Rev 20(6):670-680

Riddle L, Brinkerhoff JM, Nielsen TM (2008) Partnering to beckon them home: public-sector innovation for diaspora foreign investment promotion. Public Adm Dev 28(1):54-66

Riddle L, Hrivnak GA, Nielsen TM (2010) Transnational diaspora entrepreneurship in emerging markets: bridging institutional divides. J Int Manag 16(4):398-411

Safran W (1991) Diasporas in modern societies: myths of homeland and return. Diaspora 1(1):83-99

Silverman D (2000) Doing qualitative qesearch. Sage, London

Smallbone D, Kitching D, Athayde R (2010) Ethnic diversity, entrepreneurship and competitiveness in a global city. Int Small Bus J 28(2):174-190

Smallbone D, Welter F (2001) The distinctiveness of entrepreneurship in transition economies. Small Bus Econ 16(1)249-262

STATA (2011) Stata Base reference manual - release 12. Stata Press, Texas

Tonoyan V, Strohmeyer R, Habib M, Perlitz M (2010) Corruption and entrepreneurship: how formal and informal institutions shape small firm behavior in transition and mature market economies. Entrep Theory Pract34(5):803-832

Turner T (2010) The jobs immigrants do: issues of displacement and marginalisation in the Irish labour market. Work Employ Soc 24(2):318-336

UNHCR (2018) Global trends: forced displacement in 2016. UNCHR, Geneva

United Nations (2017) International migration report. UN, New York

Vaaler PM (2013) Diaspora concentration and the venture investment impact of remittances. J Int Manag 19(1):26-46

Vershinina N, Barrett R, Meyer M (2011) Forms of capital, intra-ethnic variation and Polish entrepreneurs in Leicester. Work Employ Soc 25(1):101-117

Vorley T, Williams N (2016) Between petty corruption and criminal extortion: how entrepreneurs in Bulgaria and Romania operate within a devil's circle. Int Small Bus J 34(6):797-817

Wang Q, Liu CY (2015) Transnational activities of immigrant-owned firms and their performances in the USA. Small Bus Econ 44(2):345-390

Williams N (2018) Mobilising diaspora to promote homeland investment: the progress of policy in postconflict economies. Environ Plan C Polit Space. https://doi.org/10.1177/2399654417752684

Williams N, Krasniqi BA (2018) Coming out of conflict: how migrant entrepreneurs utilise human and social capital. J Int Entrep 16(2):301-323

Williams N, Vorley T (2015) Institutional asymmetry: how formal and informal institutions affect entrepreneurship in Bulgaria. Int Small Bus J 33(8):840-861

Williams N, Vorley T (2017) Creating institutional alignment and fostering productive entrepreneurship in new born states. Entrep Reg Dev 29(5/6):444 446

Williams N, Radevic D, Gherhes C, Vorley T (2017a) Corruption and entrepreneurship in new born states: some lessons from Montenegro. South East Eur J Econ Bus 12(2):31-45

Williams N, Vorley T, Williams CC (2017b) Entrepreneurship and institutions: the causes and consequences of institutional asymmetry. Rowman and Littlefield, London

World Bank (2016) Migration and development. World Bank, Washington

Zaheer S (1995) Overcoming the liability of foreignness. Acad Manag J 38:341-363

Zbinden M, Dahinden J, and Efendic A (eds) (2016) Diversity of migration in South-East Europe. Peter Lang AG, Bern

Publisher's note Springer Nature remains neutral with regard to jurisdictional claims in published maps and institutional affiliations.

\title{
Affiliations
}

\section{Nick Williams ${ }^{1} \cdot$ Adnan Efendic $^{2}$}

\author{
Nick Williams \\ N.E.Williams@leeds.ac.uk
}


Adnan Efendic

adnan.efendic@efsa.unsa.ba

1 Charles Thackrah Building, University of Leeds, Clarendon Road, Leeds LS2 9LB, UK

2 School of Economics and Business, University of Sarajevo, Trg Oslobodnjea A.I. 1, 71000 Sarajevo, Bosnia and Herzegovina 